\title{
GEOGRAFIA E HISTÓRIA DA ARTE: APONTAMENTOS PARA UMA CRÍTICA À ICONOLOGIA
}

- ANDRÉ REYES NOVAES

Resumo: A "escola" de historiadores da arte formada em torno das ideias de Aby Warburg no início do século XX tem tido influência peculiar nas trocas entre as teorias artísticas e 0 trabalho de geógrafos. Interessados em discutir os significados de paisagens, mapas, fotografias e pinturas, muitos autores têm se apropriado da iconografia e da iconologia como ferramentas metodológicas. Por meio da discussão de duas críticas direcionadas ao método iconológico - o perigo dos argumentos circulares e a negligência do observador , o presente artigo busca estimular um debate interdisciplinar que potencialize 0 uso de imagens como fonte de informação no trabalho dos geógrafos.

Palauras-Chave: Iconologia, Geografia, História da Arte.

Introdução

Os termos iconografia e iconologia são recorrentes no trabalho dos geógrafos humanos a partir do final da década de 1980. Mas, apesar da existência de uma discussão consolidada na disciplina, muitas vezes estes termos ainda são utilizados simplesmente como sinônimos de imagem: "a iconografia do trabalho está em anexo", "estou estudando a iconografia da cidade". Nestes casos, a iconografia parece ser um objeto de estudo, uma palavra usada para designar conjuntos de imagens como fotos, mapas e gravuras que serviram de fonte de informação para o trabalho do geógrafo. No presente artigo, buscarei evidenciar como a iconografia e a iconologia são métodos de análise das imagens desenvolvidos no âmbito da história da arte. Ao discutir as potencialidades e as limitações destes métodos, o artigo busca 
estimular um debate interdisciplinar que potencialize o uso de imagens como fonte de informação no trabalho dos geógrafos.

A história da arte pode ser considerada como a "mais longa disciplina acadêmica continuamente preocupada com o estudo dos artefatos visuais" (MANGHANI et al, 2006:83), o que faria dela um "ponto de partida essencial para qualquer pesquisa visual" (ROSE 2001:144). Não por acaso, muitos geógrafos vão buscar nesse campo ferramentas metodológicas para discutir os contextos sociais de produção e difusão das imagens. Mas quais historiadores da arte apareceriam com maior frequência no trabalho dos geógrafos? Quando os geógrafos Cosgrove e Jackson (2000:22) escrevem que "a iconografia dos historiadores da arte é o melhor método de interpretação das imagens já desenvolvido", estes autores estão se referindo basicamente à metodologia proveniente da escola de Aby Warburg (1866 1922), historiador da arte alemão que criou uma biblioteca no final do século XIX e transformou significativamente a forma de se conceber a história das imagens ao longo do século XX.

Contrastando com a forma vigente de se contar a história da arte na época, majoritariamente marcada por enfoques evolucionistas que buscavam identificar o progresso das técnicas de representação através do destaque de autores e obras selecionadas, Warburg reuniu uma biblioteca de $65 \mathrm{mil}$ volumes onde "a história da arte enquanto disciplina acadêmica era submetida à prova de uma desorientação ordenada" (DIDI-
HUBERMAN, 2002:41). Sem seguir uma ordem cronológica, ou agrupar as imagens a partir de escolas ou tendências pré-definidas, a biblioteca permitia fazer novos tipos de conexão entre imagens de diferentes épocas e espaços e seria, como afirmou um de seus discípulos, Fritz Salx (1980 - 1948), um bom lugar para "encontrar problemas" (DIDIHUBERMAN, 2002). Defendendo uma história da arte interdisciplinar que permitisse articular arte e cultura, Warburg utilizou os recursos financeiros de sua família judia para comprar diversas obras e viabilizar estudos que combinavam vários tempos, formas, erudições e espaços.

O medo de que os nazistas se apropriassem do material levantado pelo autor estimulou que Salx transferisse a biblioteca para Londres após a morte de Warburg. Em 1944, a biblioteca foi absorvida pela University of London e o Warburg Institute é, até os dias atuais, uma respeitada biblioteca e um importante centro de pesquisa. Foi principalmente a partir das ideias difundidas pelos discípulos de Warburg, como Fritz Salx, Erwin Panofsky (1892-1968) e Ernest Gombrich (1909-2001) que muitos geógrafos tiveram contato com os termos iconografia e iconologia. Principalmente o trabalho de Panofsky tem sido muito citado, no intuito de justificar a aplicação do método iconográfico/iconológico para se estudar os "valores simbólicos" de paisagens (COSGROVE e DANIELS, 1987), mapas históricos (HARLEY e BLAKEMORE, 1980), 
imagens midiáticas (KOSONEN, 1999) entre outros objetos. Até mesmo na geografia brasileira já se pode encontrar uma relativa difusão destes métodos, que foram discutidos em trabalhos sobre mapas (NOVAES, 2005, 2007, 2008), monumentos (CORREA, 2007) e cenários (GOMES, 2008).

Para além de apenas apresentar os já conhecidos caminhos de interpretação das imagens desenvolvidos pelos historiadores da arte, o que já foi feito em muitos dos trabalhos citados acima, o presente artigo busca oferecer alguns apontamentos a partir de duas críticas ao método iconológico que podem ser úteis para pesquisas geográficas contemporâneas: o perigo dos argumentos circulares e a negligência do observador. Seguindo os passos críticos do historiador italiano Carlo Ginzburg (1989), que também passou pelo Warburg Institute, buscarei, inicialmente, problematizar a função das imagens na pesquisa histórica e geográfica. Embora muito recorrentes, as imagens muitas vezes não são apropriadas enquanto fontes suis generis de informação e acabam apenas ilustrando dados previamente "conhecidos por outras vias", funcionando como "argumentos circulares" relacionados aos textos escritos (GINZBURG, 1989). Por outro lado, o reconhecimento dos "limites da iconologia" (GOMBRICH，1996) também pode estimular uma valorização do papel do observador nos processos de significação e comunicação através de imagens.

$\mathrm{O}$ uso de imagens como uma fonte documental que simplesmente registra e descreve a "realidade" espacial já vem sendo criticado há bastante tempo na geografia, estimulando debates importantes sobre o papel da visualidade na disciplina (i.e ROSE, 2003). A articulação entre imagens, contextos históricos e discursos políticos específicos vem gerando trabalhos muito interessantes e inovadores neste campo disciplinar. No entanto, esta trilha pode nos conduzir a armadilhas já identificadas e apontadas há bastante tempo pelos historiadores da arte. No presente artigo, buscarei identificar a existência de possíveis armadilhas para uma pesquisa que utiliza imagens como fonte de informação histórica, mas não há, aqui, a pretensão de oferecer caminhos de fuga ou rotas alternativas.

$\mathrm{Na}$ primeira seção, buscarei apresentar muito brevemente as linhas gerais do que se poderia chamar de "iconologia", discutindo as suas raízes históricas e o desenvolvimento de um projeto de renovação da história da arte relacionado à figura e ao "método" de Aby Warburg (WOODFIELD, 2001). Posteriormente, discutirei as duas críticas ao método iconológico previamente esboçadas: a existência de argumentos circulares e a negligência do observador. Através desta discussão crítica do uso das imagens como fonte de informação na história da arte, busca-se entender os limites e potencialidades que os artefatos visuais podem oferecer para uma pesquisa geográfica. 
Abordagem Iconológica e a "Invenção" de um Método

Segundo Heckscher (1985), a tarefa de se discutir a "gênese da iconologia" oferece dois caminhos. O primeiro estaria relacionado com o resgate das raízes do termo, já presente em documentos do século XVI, como no texto frequentemente citado de Cesare Ripa, chamado "Iconologia". O segundo seria evocar o desenvolvimento da "iconologia moderna", que surge no início do século $\mathrm{XX}$ através do trabalho de Aby Warburg. Assim como em Heckscher (1985), este trabalho segue o segundo caminho que possibilita um debate mais profundo sobre a criação de uma metodologia de análise das imagens. No entanto, mesmo que a preocupação aqui recaia sobre a chamada "iconologia moderna", é importante justificar minimamente porque historiadores da arte do início do século XX desenvolveram conceitos inspirados em terminologias renascentistas.

Além de serem estudiosos e profundos conhecedores deste período, autores como Warburg e Panofsky viram nas ideias de Cesare Ripa o germe de uma possível relação entre as obras de arte e seus "significados intrínsecos". Como destaca Straten (1994:4), "nós não sabemos praticamente nada sobre a vida de Cesare Ripa" e a referência ao seu trabalho geralmente ocupa notas de pé de página bastante modestas, principalmente no trabalho dos geógrafos (ver COSGROVE e DANIELS, 1987). Sabe-se que Cesare Ripa nasceu por volta de 1560 em Perugia e publicou a primeira edição de "Iconologia" em Roma no ano de 1593 (STRATEN, 1994). No livro, que foi diversas vezes reeditado, Ripa apresentava mais de mil "personificações" organizadas em ordem alfabética, descrevendo minuciosamente como utilizar imagens para representar desde a "abundância" (abondanza) até o "zelo" (zelo).

Segundo Gombrich (1999:129), o ato de "personificar conceitos abstratos em termos de presenças vivas" era uma tradição muito comum no mundo mitológico da Grécia e de Roma que segue sendo aplicado até a atualidade. Retomando essa tradição no contexto da Renascença, a "Iconologia" de Ripa tornou-se um "best seller" da época (STRATEN, 1994), e sua terceira edição, de 1603, já contava com uma série de imagens feitas através de prensas de madeira. Ao longo do século XVII, o livro teve mais de vinte edições, funcionando como um dicionário simbólico para captar o sentido das pinturas.

Se um artista buscava, por exemplo, exprimir o conceito de verdade, este podia recorrer à descrição textual ou à imagem oferecida por Ripa (fig.1). A verdade seria, portanto, "uma mulher bonita e nua, com sua mão direita erguendo um sol radiante para onde ela olha, e na sua outra mão posiciona-se um livro aberto e um ramo de palmeira, em baixo do seu pé direito ela tem um globo celeste" (STRATEN, 1994:18). É difícil saber o quanto estas figuras eram tiradas da tradição mitológica ou por vezes inventadas por Ripa, mas o fato é que a "Iconologia" ajudou no desenvolvimento 
de um vocabulário imagético que possibilitou a exprimir e relacionar conceitos abstratos. comunicação entre artista e público para
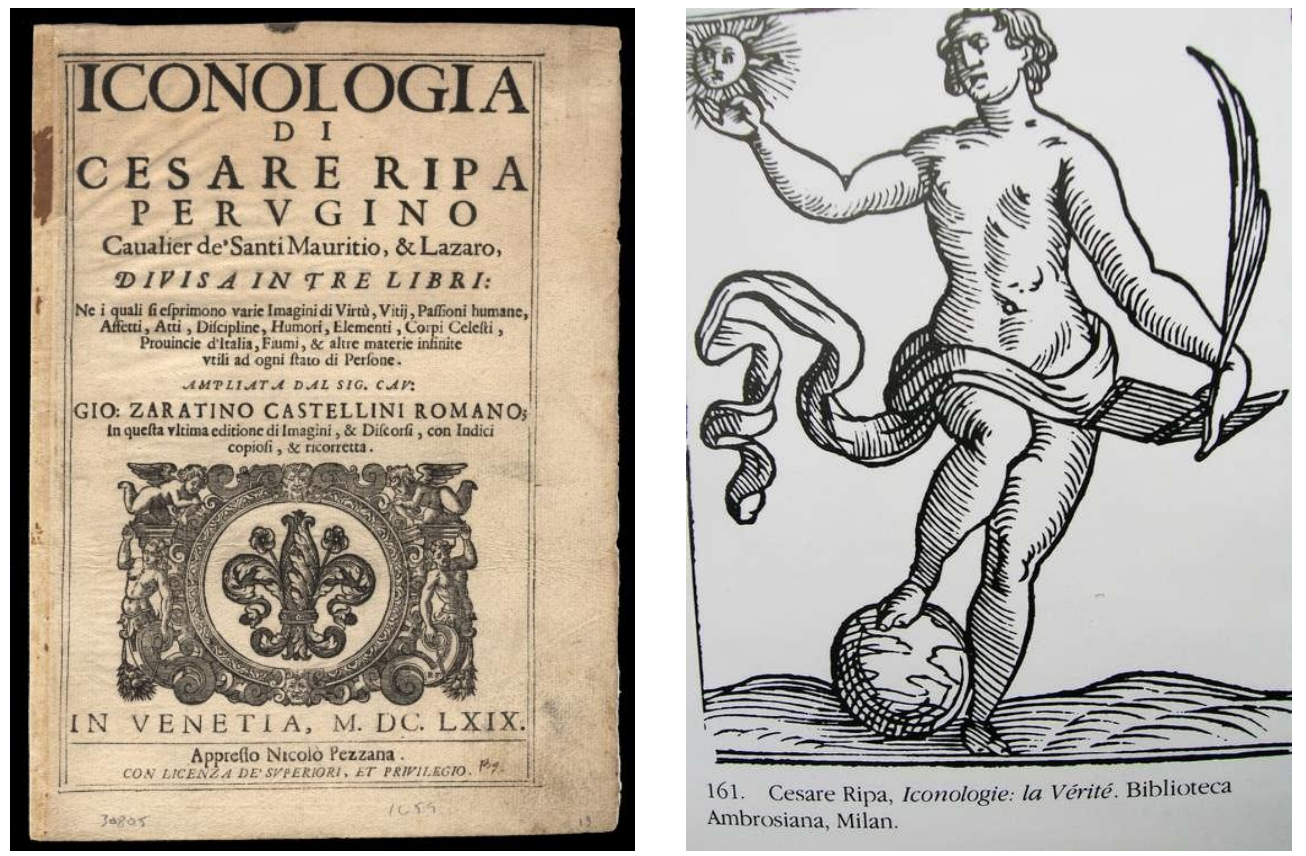

Figura 1: Iconologia de Cesare Ripa. Fonte. http://www.haltadefinizione.com/en/

A existência de um vocabulário compartilhado contribuiu para que os/as artistas pudessem combinar "personificações" distintas, gerando alegorias e narrativas. A partir de um suporte exclusivamente imagético, seria possível assim mostrar o "tempo revelando a verdade" ou a "paz e a justiça se beijando". Muitos destes encontros alegóricos também envolveram espaços, que não raramente foram "personificados", possibilitando, por exemplo, representar só com imagens um "aperto de mãos" entre a "Gália" e a "Bélgica" (GOMBRICH， 1999:129). Relacionando imagem e significado, a "Iconologia" de Cesare Ripa auxiliou nas interpretações de muitos trabalhos do século XVII e XVIII, que, mesmo sem seguirem com precisão as indicações simbólicas do autor, tinham o seu dicionário como ponto de partida para a construção de um programa alegórico específico.

Porém, segundo Starten (1993), o realismo do século XIX desvalorizou a "personificação" e o trabalho de Cesare Ripa caiu no esquecimento. Por este motivo, o termo iconologia foi pouco utilizado na história da arte até o início do século XX. Foi apenas no início do século passado que alguns autores passam a ver a iconologia como uma importante fonte de inspiração para relacionar as imagens com seus significados e conteúdos históricos. Seguindo a 
história do termo no século $\mathrm{XX}$, a iconologia teria nascido no mês de outubro de 1912, quando Warburg utiliza o termo "análise iconólogica" pela primeira vez como uma ideia chave de sua palestra no congresso de historiadores da Arte em Roma (HECKSCHER, 1985:239).

Aprofundando esta ideia nos anos seguintes, Warburg passa a ser reconhecido como criador de um método distinto de análise das imagens artísticas, o que lhe rendeu vários elogios em artigos publicados no início do século XX (GINZBURG，1989). Distinguindose de historiadores da Arte que seguiam uma corrente clássica formalista, como Wölfflin, que se propunham a anular qualquer ligação entre história da arte e história da cultura, o autor será pioneiro na busca por estabelecer relações entre as imagens artísticas e o contexto em que foram criadas, estimulando uma "história da imagem do ponto de vista cultural" (GINZBURG, 1989:47).

A principal ferramenta utilizada por Warburg para ultrapassar as barreiras disciplinares e driblar a "polícia de fronteira" foi o que o autor chamou de "análise iconológica". A partir deste método, que relacionava imagem, história e cultura, o historiador da arte não estaria mais preocupado apenas com as classificações estilísticas e formais, mas, sim, com as possíveis "implicações políticas e religiosas sugeridas pela escolha particular de um tema e a forma como este é representado" (CASSIDY, 1993: 5). Neste sentido, Warburg é pioneiro na abertura de um "programa interpretativo" na história da arte, fundando uma agenda de pesquisa que relaciona a produção de imagens artísticas com "valores simbólicos" existentes na sociedade (PANOFSKY, 1979).

Segundo Ginzburg (1989: 56), Warburg abre uma nova frente de pesquisa sobre as imagens artísticas no início do século $\mathrm{XX}$, pois seu trabalho apresentava um objetivo duplo que renova este campo de estudo. Por um lado, era preciso considerar as imagens a partir de testemunhos históricos que esclarecessem a gênese de seu significado e suas articulações com o quadro da época. Daí a importância que o autor dava à coleção de fontes pouco usuais e sem aparente "valor estético", como os selos e os panfletos populares. Por outro, as próprias imagens e figurações deveriam ser interpretadas como fontes sui generis para a reconstrução das concepções sociais existentes em um dado momento.

O debate sobre o uso das imagens como fonte de informação histórica atravessou toda a obra de Warburg. Partindo do objetivo específico de discutir o significado da Antiguidade Clássica para a cultura artística da Renascença, o autor se debruçou sobre a representação do movimento do corpo, cabeleiras e vestes nas figuras do Quattrocento Fiorentino. Através de aspectos formais, seria possível remontar as "atitudes fundamentais" da época, considerando as imagens como "testemunhos de estados de espírito". Assim, seria possível afirmar, por exemplo, que a Antiguidade "dionisíaca" teve uma influência 
marcante na construção das imagens renascentistas, pois estas seriam predominantes nas "imagens mentais" que artistas, patronos e poetas tinham dos mitos clássicos (GOMBRICH, 1999).

Ao defender uma história da arte que desembocasse em uma teoria da cultura Kulturwissenshaft - Warburg torna inviável qualquer possibilidade evolucionista de leitura das imagens. Como destaca Gombrich (1999), a abordagem do autor evidencia que a História da Arte não pode ser contada como uma evolução contínua nas formas de se copiar a natureza, o que era bastante comum antes de suas contribuições. A passagem dos pré-Rafaelistas para os pós-Rafaelistas, por exemplo, era geralmente vista como uma "evolução", pois os artistas teriam incorporado novas habilidades para "copiar a natureza", representando com maior precisão os músculos e expressões humanas (GOMBRICH, 2001:36). Já na concepção de Warburg, a necessidade de registrar o movimento do corpo humano, elemento fundamental na "imagem mental" que muitos patronos tinham da arte da antiguidade, afastava os pintores renascentistas de qualquer pretensão mimética, pois o movimento na pintura é geralmente representado por sugestão, pressupondo mais imaginação do que observação da natureza.

Esta abordagem evolutiva e tecnicista, tão recorrentemente criticada por Gombrich (1996), aparece com frequência no discurso dos geógrafos sobre as imagens. As expedições geográficas, por exemplo, que eram inicialmente ilustradas com desenhos esquemáticos e pinturas, teriam "melhorado" sua forma de "registrar a natureza" a partir das novas técnicas fotográficas e cinematográficas. A evolução das técnicas de mapeamento teria aprimorado a forma de se representar o terreno e as expedições seriam como uma "luz clara" que nos revela o conhecimento dos espaços, agora representados de forma mais objetiva (ALLEN, 1971). Buscando refutar esta forma evolucionista de entender as imagens, muitos autores vão buscar na iconografia e na iconologia dos historiadores da arte a inspiração para relacionar as imagens com seus contextos de criação, procurando entender os processos de produção e circulação das imagens artísticas para associá-las com seus "valores simbólicos".

Mas até que ponto seria possível reivindicar um "método warburgniano" para se interpretar as imagens em trabalhos realizados no âmbito da Geografia? Até que ponto podese afirmar que Warburg e seus seguidores desenvolveram, de fato, um método convincente de uso das imagens como documentos históricos, ou "testemunhos sobre o quadro de uma época"? De acordo com Ginzburg (1989), um passo inicial importante para aqueles que querem reivindicar o "método warburgniano" para alguma pesquisa específica, seria questionar o seu valor intrínseco. É importante, também, "esclarecer até que ponto a obra de Warburg foi levada à frente por seus seguidores" (GINZBURG, 1989:42), conhecendo debates internos dos historiadores 
da arte no intuito de identificar contribuições e armadilhas do chamado "método iconológico".

\section{Argumentos Circulares e o uso da Imagem como Ilustração}

Os processos de tradução são certamente um elemento fundamental na circulação de ideias e estes foram muito importantes na forma como os estudos de Warburg foram absorvidos pela comunidade científica "internacional", leia-se anglo-saxônica. Com a exceção de um texto relativamente pequeno publicado no Journal of the Warburg Institute, em 1939, os escritos de Warburg permaneceram sem tradução para o inglês até $\mathrm{o}$ final da década de 1980. Este fato fez com que suas ideias fossem apresentadas não a partir de seus textos, mas, sim, através de seus discípulos mais imediatos, como Salx e Panofsky.

A situação política da Alemanha no início do século XX fez com que a carreira dos historiadores da Arte que seguiam as ideias de Warburg fosse construída em um ambiente acadêmico basicamente anglo-saxão. Enquanto Salx permaneceu no Warburg Institut proferindo uma série de palestras para um público variado em Londres, Panofsky optou por cruzar o Atlântico e se tornou um grande difusor das ideias de Warburg no crescente meio acadêmico norte-americano. Juntos, estes autores escreveram seu primeiro ensaio em inglês em 1933, Classical Mythology in Medieval Art, no qual buscam, através do "exame de um problema singular", "demonstrar o método de pesquisa desenvolvido por Aby Warburg e seus seguidores" (SALX, 1957: 229). Para alguns autores, como Woodfield (2001), os seguidores de Warburg teriam, na realidade, inventado o seu método de forma bastante "ficcional" e "arbitrária".

Iniciaremos a análise deste processo de criação de uma metodologia através de alguns textos de Salx, que, segundo Ginzburg (1989), oferece ótimos exemplos sobre os perigos do uso de imagens como fonte de informação histórica. Em uma série de palestras proferidas ainda em Hamburgo na década de 1920, Salx buscava aplicar o que chamava de "método warburgniano" para estudar "a vida das imagens" (SALX, 1957). Buscando "aproximar-se de um problema histórico com instrumentos oferecidos pela história da arte", o autor estudou a atuação de artistas do século XVI na difusão de novas ideias religiosas, analisando os "panfletos ilustrados da Reforma" (SALX, 1957: 230). Seguindo os passos de Warburg, Salx (1957:239) afirmava que "as gravações em madeira, cartazes e panfletos do século XV e da Reforma não são grandes obras de arte, mas são interessantes de serem estudados como o espelho do temperamento de uma época".

Para valorizar o papel da imagem como fonte de informação histórica, Salx (1957) primeiramente evidencia a limitação de documentos textuais sobre o período. As propagandas religiosas, tanto católicas quanto protestantes, circulavam entre um público majoritariamente analfabeto nas feiras e comércios no século $\mathrm{XV}$, o que estimulava o uso 
de "panfletos ilustrados". Outro fator que limitava o uso de textos no período está relacionado com a técnica de impressão, pois, como "as primeiras gravações de madeira foram feitas no início do século XV" (SALX, 1957: 230), cada letra ainda era talhada individualmente nos blocos de madeira, o que dificultava a utilização de frases extensas. Neste sentido, o autor define as imagens panfletárias como fontes de informação sobre o período da Reforma, considerando que os textos que os acompanham servem de dados adicionais. Buscando aplicar uma abordagem iconológica, o autor considera como "palavras e imagens juntas evocam um retrato vivo" (SALX, 1957: 239), sendo fundamentais no estudo das relações entre os artistas da época e as novas correntes religiosas que emergiam.

Ginzburg (1989) não chama atenção para este fato, mas Salx parece minimamente consciente dos riscos que corria. Logo no início de seu texto sobre "Holbein e a Reforma", ele alerta que, "se tentarmos entender a linguagem pictórica, quer dizer, a linguagem das formas, nós sempre nos arriscaremos a que se debilitem ou se frustrem nossos esforços (...)" (SALX, 1957: 215). Um dos perigos que o autor diz que procura evitar, "se puder", é o de projetar os seus "próprios valores" para analisar as imagens do passado. De qualquer forma, Salx parecia acreditar que as imagens poderiam auxiliá-lo na criação de um "método histórico objetivo" que poderia revelar, por exemplo, as relações entre Holbein, considerado o artista mais representativo da Reforma alemã, e Lutero, o principal líder deste movimento.

A pergunta histórica proposta por Salx se relacionava com as posições religiosas de Holbein, indagando se este artista era protestante e se ele havia seguido fielmente as propostas de Lutero. Recorrendo à imagem como fonte de informação, Salx responde à primeira questão a partir de uma gravação em madeira feita por Holbein (fig.2). A imagem é centrada em uma forte luz que divide dois grupos que não trocam olhares. À direita, observamos os monges, o Papa e até Aristóteles, todos de cabeça baixa, iniciando a descida rumo a um abismo e uma paisagem montanhosa. À esquerda, saindo das árvores, aparecem diversos "tipos" populares, como "o jovem burguês", o "devoto de maior idade", "o velho descalço" e a "jovem com a matrona" (SALX, 1956: 250). O povo parece, assim, encontrar a "luz" de forma direta, sem a interferência dos intermediários de Roma. 


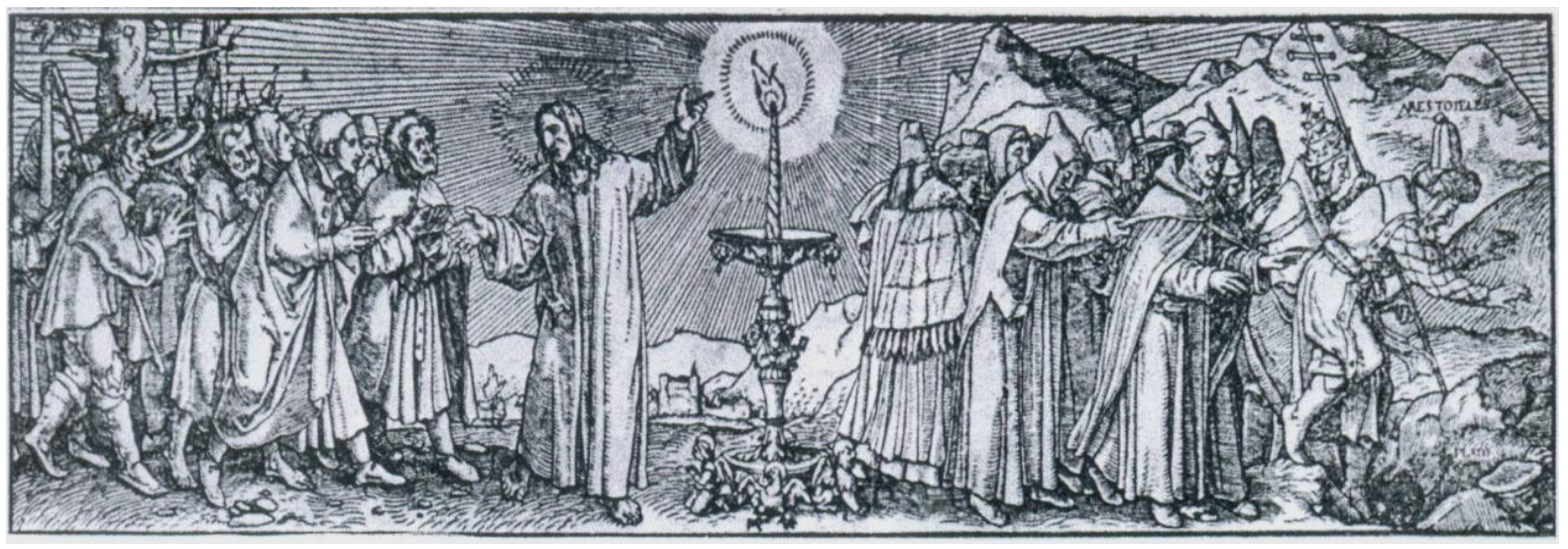

Figura 2: Gravura de Holbein. Fonte. Fritz Salx (1957).

Segundo Salx (1957), a "mensagem do cartaz é clara" e reflete os valores religiosos do artista e de certos grupos na sociedade europeia do século XIV, que tinham o objetivo de difundir propagandas anti-romanas. Uma imagem como essa certamente evidencia a posição ideológica e religiosa de Holbein que, não por acaso, ficou conhecido como o grande ilustrador dos panfletos reformistas. Mas, como destaca Ginzburg (1989:59), Salx insiste em sua segunda pergunta: até que ponto os panfletos de propaganda compostos por Holbein não são apenas anti-romanos, mas, também, "refletem o espírito de Lutero"?
Para responder a esta indagação, Salx compara as gravuras de Holbein com outras imagens luteranas que circulavam para o público no mesmo período. Segundo Salx, essas imagens eram geralmente muito "agressivas" e "vulgares", utilizando, por exemplo, figuras monstruosas de um asno para representar o Papa e seus seguidores. Na gravura de Freyberg (fig,3), feita para um panfleto de Lutero difundido em 1523, vemos o desenho de um "monge-bezerro", sugerindo que a direção da Igreja estaria sendo dada por uma "cabeça de burro" (SALX, 1957: 233). 


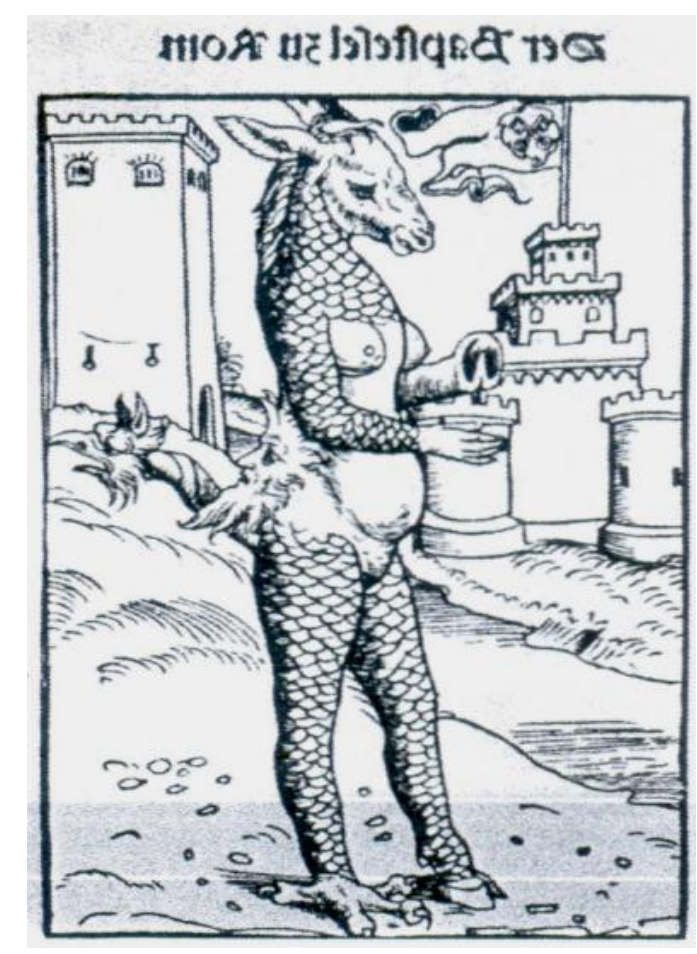

Figura 3: Gravura de Freyberg. Fonte. Fritz Salx (1957).

Comparando essas gravuras explicitamente luteranas com os trabalhos de Holbein, Salx (1957) procura utilizar a linguagem pictórica para responder a sua indagação. Eis, aqui, um exemplo de como se pode chegar a uma conclusão histórica utilizando apenas as formas e significados existentes nas imagens como fonte de informação: a comparação entre as gravuras revela que Holbein era anti-romano, mas ainda não havia se convertido ao Luteranismo. Este seria responsável pela difusão de imagens mais "agressivas", enquanto as criações do artista seriam caracterizadas pela claridade e a manutenção de formas naturais. Os inimigos romanos e seus seguidores aparecem em Holbein geralmente como derrotados e ingênuos, e não como monstros ou anomalias.
O trabalho de Salx representaria, assim, o sucesso do método de Warburg, evidenciando como as imagens podem revelar concepções existentes na sociedade? Ginzburg (1989:61) discordaria radicalmente de qualquer resposta positiva a esta pergunta, pois o autor utiliza este caso justamente para explicitar "os riscos ligados a um método". Ginzburg (1989) nos recorda de que a imagem é uma fonte de informação inevitavelmente mais ambígua e aberta a interpretações distintas. A identificação de concepções sociais através de uma pesquisa que considera exclusivamente documentos figurativos pode ser perigosa.

Para caracterizar as imagens luteranas, Salx escolheu uma figura extrema representando monges monstruosos com caras de burro, mas Ginzburg (1989) alerta para o fato de que há 
uma extrema subjetividade no método desenvolvido por Warburg. Caso Salx escolhesse outras imagens luteranas, como as de Cranach, não chegaria às mesmas conclusões, pois não encontraria as características de "vulgaridade" e "agressividade" relacionadas diretamente a Lutero. $\mathrm{O}$ perigo de se considerar as imagens como documentos figurativos, que nos relatam concepções existentes na sociedade, seriam justamente os chamados "argumentos circulares". Para Ginzburg (1989), documentos de outra natureza já informavam Salx de que Holbein não era luterano e o uso da imagem teve apenas o papel ilustrativo, confirmando uma informação pré-existente. Nesse sentido, ao utilizar os documentos figurativos como fonte de informação, frequentemente o pesquisador apenas "lê neles o que já sabe, ou crê saber, por outras vias" (GINZBURG, 1989: 63).

De fato, Salx (1957: 250) já sabia que, nos "registros de recrutamento", Holbein era classificado como "de acordo com outros

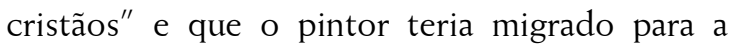
Inglaterra no final de sua vida, trabalhando para um dos principais inimigos de Lutero, Henrique VIII. O objetivo aqui não é aprofundar dados históricos, mas apenas evidenciar como muito frequentemente corre-se o risco de utilizar imagens em uma pesquisa apenas como uma forma de reforço ou ilustração, favorecendo a existência de "argumentos circulares". Certamente é um grande avanço considerar as imagens como "espelho de uma época", buscando extrair as ideias e os contextos históricos que permearam sua construção. No entanto, segundo Ginzburg (1989), seria fácil demais confirmar uma velha tese utilizando material figurado se interpretamos este material pressupondo a comprovação da tese.

As imagens muitas vezes aparecem no discurso científico como "profecias que se autocumprem", "demonstrações" do previamente anunciado. Até que ponto extraímos informação das imagens em nossas pesquisas ou apenas as utilizamos para ilustrar afirmações previamente formuladas? Esta é uma pergunta difícil de ser respondida. Porém, pode-se afirmar que as imagens frequentemente acompanham o discurso do geógrafo de forma "comprobatória", "autoritária" e "ilustrativa". Apresentadas em auditórios de congressos e salas de aula, as imagens geralmente seguem o fluxo contínuo da narrativa, normalmente organizadas de uma forma que pareçam "demonstrar" o argumento exposto oralmente (ROSE, 2003). A relação entre imagem e "contexto social" geralmente é feita de forma bastante imediata e a ideia de que as imagens "exprimem" pontos de vista é pouco problematizada. A informação é ilustrada pela imagem, mas pouca informação realmente sai da leitura da imagem.

Os Limites da Iconologia e a Participação do Observador

O desafio de utilizar as imagens como fonte de informação histórica também foi 
importante para outros estudiosos envolvidos com a chamada "escola" de Warburg. Ao traduzir para o inglês seus ensaios em uma coleção chamada Studies in Iconology, publicada em 1932, Panofsky foi, talvez, o principal divulgador do trabalho de Warburg e seus textos vêm sendo frequentemente apropriado por geógrafos e cartógrafos preocupados em estabelecer relações entre imagem e significado (i.e COSGROVE, 1998 e HARLEY, 1988). Definindo diferentes "níveis de significado" existentes em uma imagem, Panofsky teria dado aplicabilidade às tendências interpretativas de Warburg.

Partindo da ideia de que existe uma inseparabilidade entre o conteúdo e o dado formal de uma obra de arte, Panofsky estudou primordialmente a Arte renascentista, por ele descrita e interpretada. Porém, seu trabalho é geralmente citado para diferenciar três níveis de significados existentes nas imagens: um nível natural (pré-iconográfico), um nível convencional (iconográfico) e um nível intrínseco (iconológico). O nível natural, cuja análise conduz a um levantamento préiconográfico, seria elementar e facilmente compreensível, tendo relação com a identificação de formas puras. Assim, primeiramente, é possível identificar os motivos e significados primários de um quadro, relacionando a suas linhas cores e volumes para concluir que este representa, por exemplo, pessoas sentadas em uma mesa.
Já no nível convencional, cuja identificação conduz a uma análise iconográfica, há uma ligação entre os motivos artísticos e assuntos específicos. Neste nível, identifica-se um significado secundário onde o observador familiarizado percebe que "um grupo de figuras, sentadas a uma mesa de jantar numa certa disposição e pose, representa a Última Ceia" (PANOFSKY, 1979: 50). Por último, pode-se definir um nível de significado intrínseco ou conteúdo das imagens, identificando, a partir de uma abordagem iconológica, "a atitude básica de uma nação, de um período, classe social, crença religiosa ou filosófica" que poderia estar "condensada numa obra" (PANOFSKY, 1979: 52).

A partir da concepção de que uma imagem poderia conter manifestações de "valores simbólicos" básicos e gerais, Panofsky (1979: 53) formula teoricamente a possibilidade de se considerar uma imagem famosa como a "Última Ceia" como "um documento da personalidade de Leonardo, ou da civilização da Alta Renascença italiana". Assim, o autor define as bases metodológicas de sua abordagem iconográfica e iconológica, a partir das quais o dever do estudioso seria alcançar as últimas camadas de significado com base em uma compreensão do contexto social de criação da imagem. Daí a necessidade de utilização de "documentos que iluminam as tendências políticas, poéticas, religiosas, filosóficas e sociais da personalidade, do período, do país em estudo" (PANOFSKY, 1979). 
Embora sejam bastante tentadores, os caminhos propostos por Panofsky conduzem a questões muito similares àquelas encontradas no trabalho de Salx. Se, para Salx, as imagens seriam o "espelho de uma época", para Panofsky, os aspectos formais das imagens deveriam ser entendidos enquanto "documentos" que poderiam revelar a "concepção de mundo contida na obra". Nesse sentido, a figura de Panofsky segue controversa. Para alguns, ele teria sido o "Saussurre da história da arte" (ARGAN, 1980), antecipando algumas colocações de Foucault com relação à "arqueologia" da representação (KWINTER, 1991). Para outros, a iconologia não teria promovido uma hermenêutica da cultura especialmente útil, pois oferece um método basicamente "tautológico" que vincula, de forma simplista e imediata, as imagens visuais e suas "totalidades históricas" (WOOD, 1991).

Segundo Ginzburg (1989), o próprio Panofsky parecia estar perfeitamente consciente da natureza "subjetiva e irracional" da abordagem iconológica. $\mathrm{Na}$ ausência de documentos textuais que atuem como um "efeito corretivo" na análise histórica das imagens, o autor sugere que o pesquisador deve contar com uma "intuição sintética" que "pode se desenvolver mais num leigo de talento do que num erudito especialista" (GINZBURG, 1989:70). Esta necessidade de estabelecer uma conexão "sintética" entre imagem e contexto histórico gerou muitas críticas à iconologia, que, para Mitchell (1994:23), seria muitas vezes incapaz de representar as "falhas na cultura, as fraturas na representação e a resistência dos espectadores". Para o autor, a questão do espectador seria o ponto "inacabado" da obra de Panofsky que seguiu sem ser enfrentado por décadas nos estudos dos historiadores da Arte.

Ao seguirem o famoso "método" de Warburg de forma bastante estandardizada, muitas gerações de historiadores da Arte do século XX se enfurnaram em bibliotecas e arquivos históricos com a esperança de encontrar informações que pudessem "revelar" o significado de uma pintura específica e suas relações com "quadro da época" (CASSIDY, 1993). Mas até que ponto o significado de uma imagem pode ser buscado em um arquivo de biblioteca? Indo mais além, haveria mesmo "um significado" a ser revelado nas imagens? Em que medida a necessidade de relacionar a imagem com "valores simbólicos" e "totalidade histórica" não tira do método iconológico a possibilidade de considerar "interpretações conflitantes" e "resistências"? Estas perguntas nos conduzem à segunda questão problemática relacionada com o método iconológico, que seria a sua limitada consideração para o que Gombrich (1986) chamou de "participação do observador".

Gostaria de exemplificar a importância de se considerar a "participação do observador" como uma questão fundamental para uma abordagem iconológica através de um exemplo oferecido por Gombrich (1996) em seu texto no qual se propõe a discutir os "objetivos e limites da iconologia". Comparado com seus predecessores, como Panofsky e Salx, Gombrich, que presidiu, por três décadas, o 
Warburg Institute, é um autor que apresenta uma postura mais cautelosa com relação à iconografia e à iconologia, pois problematiza as relações "fáceis" e "imediatas" entre imagens artísticas e contextos sociais amplos (GINZBURG, 1989:73). Mesmo que o autor reconheça que "já podemos ver os contornos $d a$ iconologia, que investiga a função das imagens na alegoria e no simbolismo e sua referência ao que se poderia chamar de o invisível mundo das ideias" (GOMBRICH, [1957] 1986:7, grifos do autor), há claramente em seus trabalhos uma postura crítica em relação aos "riscos" de se utilizar as imagens artísticas para se produzir afirmações generalizantes e inconsistentes.

A maior crítica de Gombrich (1986) a este método era direcionada à forma como se concebiam os estilos, quase enquanto uma "personalidade coletiva" ou uma "super obra de arte" $^{\prime \prime}$ que dominava todos os artistas de uma época e garantia a relação entre imagem e contexto histórico. Assim, todos os cartógrafos do século XIV só construíam mapas que relatavam aspectos da ordem social feudal, como os pintores do Renascimento repetiam os mesmos motivos e temas artísticos que remetiam à antiguidade. Para Gombrich (1986), haveria muitas vezes um "imediatismo" e uma "facilidade" nestas articulações entre uma obra individual e um contexto social amplo. Nesse sentido, como afirma Ginzburg (1989:79), “o terreno de Gombrich é mais firme e mais árido". Talvez por isso seu trabalho encontre uma difusão menor nas discussões sobre imagem na geografia.
Buscando re-conceitualizar a questão do estilo, Gombrich (1986) considera a relação entre o pintor e o leitor do quadro, pensando de forma pioneira a existência de um "esquema" de representação e uma função específica da imagem que influenciará sua forma. Segundo o autor, "uma mudança de função dá lugar a uma mudança de forma", pois os estilos mudam para atender às exigências distintas do espectador (GOMBRICH, 1986: 70). A imagem artística é, para Gombrich, uma "mensagem particular, que pode ser entendida pelo espectador na medida em que conhece as alternativas possíveis, o contexto linguístico em que se situa a mensagem" (GINZBURG, 1989: 76).

Embora menos claros e atraentes, os caminhos traçados por Gombrich podem ser muito úteis para o desenvolvimento de uma abordagem reflexiva sobre a circulação das imagens, considerando os "esquemas" que permitem a comunicação entre produtor e leitor. Uma incorporação mais sistemática de sua obra é, portanto, um desafio instigante para geógrafos e cartógrafos preocupados em relacionar imagem e significado.

Preocupado com os "limites da iconologia", Gombrich (1996) inicia um de seus textos descrevendo uma estátua localizada no centro da cidade de Londres (fig. 4) e tentando definir os seus significados secundários. A estátua, situada no centro da praça de Piccadilly Circus, é um marco visível na paisagem da cidade e funciona como ponto de encontro diário para vários transeuntes. Um pesquisador que fosse às bibliotecas buscar fontes de 
informação para identificar o "tema" ou "assunto" da obra reconstituiria rapidamente a história segundo a qual a estátua foi feita no final do século XIX, em homenagem ao Lord Shaftesbury, um inglês filantrópico que viveu no período vitoriano. Seguindo uma metodologia iconográfica, um historiador da arte poderia relacionar a estátua do "garoto com asas" com o mito de Eros, o que nos levaria a considerar a imagem como um símbolo de caridade, utilizado para homenagear as ações filantrópicas de um aristocrata

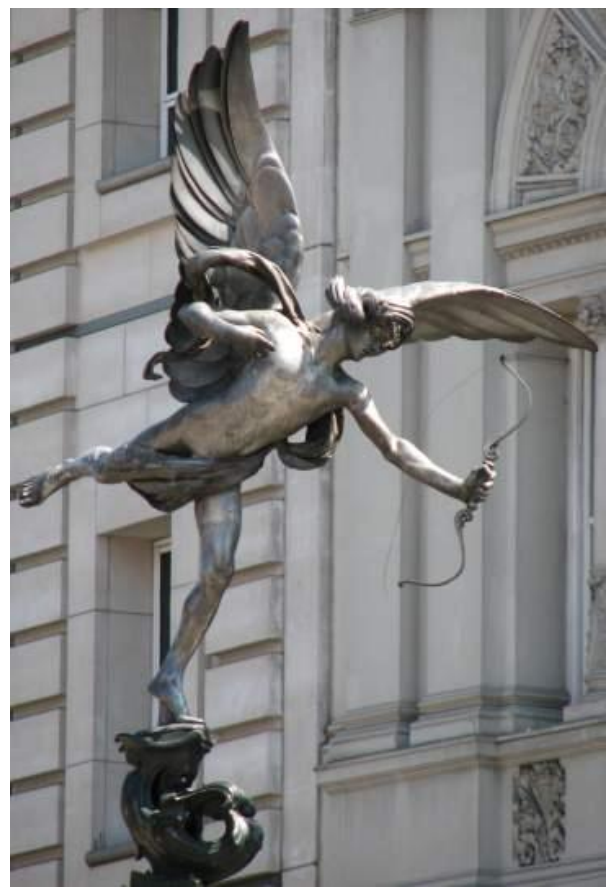

Figura 4: Estatua de Eros em Piccadilly Circus.

No entanto, Gombrich (1996) nos alerta que há uma diferença entre a intenção original de significado da figura, determinado pela "comissão memorial", e o seu "significado popular", atribuído por aqueles que passam cotidianamente pela estátua no centro de Londres. Para estes últimos, a representação de um "garoto com asas" segurando um arco nas mãos, como se disparasse uma flecha na direção de quem passa nas ruas, ganhou fama como a representação de um cupido, significado comumente associado a esta imagem na tradição ocidental. O curioso é que o autor da obra,
Gilbert, vai progressivamente aderindo às interpretações populares e, em 1911, já dava declarações como se sua estátua representasse realmente o "deus do amor". Gombrich (1996: 459) utiliza este exemplo para fazer um alerta em relação à iconologia: a ideia de procurar o "significado real" que o artista buscava na execução da obra "pode não nos levar a lugar nenhum".

Se constatamos que a estátua de "Eros significa uma coisa para os moradores de Londres e outra para o comitê memorial" (GOMBRICH, 1996:460), evidencia-se como 
pode ser problemático o objetivo de buscar um significado intrínseco único nas obras de arte, que permita associá-la a "totalidades históricas" de uma época ou período. Para Gombrich (1994: 466), é fundamental reconhecer que o significado de uma obra depende muito da "participação do observador", pois esta "não tem um significado, mas um conjunto de significados, que por sua vez são determinados pelo contexto". Nesse sentido, "a escultura não apenas abstrai a cor e a textura, ela também não pode significar nada além de si mesma" (GOMBRICH， 1994: 461); seus significados secundários podem ser remodelados no processo de apropriação e resistência dos observadores.

Por um lado, o iconólogo corre o risco de atribuir intenções estranhas ao próprio artista: "ele sabe mais sobre as minhas pinturas do que eu, ele coloca coisas na minha cabeça e aponta significados que eu nunca pretendi", afirmava o pintor inglês Turner ao ler os comentários que Ruskin fazia de suas obras (CASSIDY, 1993: 7). Por outro lado, existe o perigo de se homogeneizar os espectadores, que parecem não participar dos processos de significação das imagens e apenas as absorvem a partir do "quadro da época" em que se encontram. Buscando avançar a partir destas questões, Mitchell (1996) destaca o importante livro de Crary (1990), Techiniques of the Observer, no qual o autor discute criticamente a iconologia e destaca que, "obviamente", "não existe um único observador do século XIX, não há um exemplo que possa ser localizado empiricamente" (MITCHELL, 1996: 21).

Não se sabe exatamente como a cultura visual era experimentada em diferentes períodos históricos, no entanto, a simples preocupação em não generalizar a interpretação das imagens já desestabiliza práticas muito comumente aplicadas no trabalho de geógrafos e historiadores. Ao utilizar a imagem como "reflexo" de uma época, é comum que se deixe de lado a discussão sobre sua circulação e sua recepção. Como estas imagens chegavam às pessoas no período estudado? Em que contextos tais imagens eram vistas? Para quem foram feitas? Segundo Gombrich (1996), perguntas desse tipo podem romper com a chamada "falácia do dicionário", como se fosse possível consultar o livro de Cesare Ripa para entender "o significado" das imagens através de uma relação iconológica de "um-para-um" (GOMBRICH，1996: 472). Uma vez que as metáforas não são reversíveis, seria bastante problemático associar as imagens a apenas "um" significado, pois estas ganham vida polissêmica quando entram em contato com as vastas audiências e circulam em contextos sociais distintos.

\section{Apontamentos Finais}

"Embora tenhamos milhares de palavras sobre imagens, nós não temos ainda uma teoria satisfatória sobre elas" (MITCHELL, 1994:9). Através desta sentença provocativa, Mitchell busca estimular uma reflexão contemporânea 
sobre as imagens, procurando desenvolver uma abordagem que dilua as dicotomias clássicas no intuito de avançar na compreensão dos significados da cultura visual. Para além de uma mera comparação entre imagens e palavras ou uma simples absorção acrítica da linguística, o autor sugere o desenvolvimento de uma "picture turn" que poderia resgatar velhos debates sobre imagem feitos pelos historiadores da arte e recolocá-los considerando temáticas e problemas atuais.

De fato, os debates em torno da "escola" de Warburg parecem ainda ter muito espaço hoje em dia. Embora muitos pontos aqui apresentados soem como ultrapassados e superados, é importante reconhecer a atualidade dos textos dos autores aqui citados. Não é por acaso que estudiosos de muitas disciplinas seguem dialogando com os textos da "escola" de Warburg e que os próprios historiadores da arte continuem interessados nos textos deste autor como forma de aproximar Arte e Cultura. O historiador da arte francês Didi-Huberman, por exemplo, é um dos teóricos contemporâneos extremamente interessados nos textos de Warburg. O seu livro de 2002, L'Image Survivante - Histoire de L'Art et Temps des Fantômes selon Aby Warburg, é uma grande homenagem ao autor, pois expõe suas principais influências e trajetórias intelectuais.

Didi-Huberman é considerado um dos principais responsáveis por estimular um "renascimento" recente do interesse pelos escritos de Warburg. O autor veio ao Brasil em
2013 apresentar a exposição Atlas, que explora as metodologias de montagem desenvolvidas pelo estudioso alemão. A proposta do Atlas, nome que já era utilizado na exposição montada por Warburg em sua biblioteca, seria criar conexões entre imagens de épocas e espaços completamente distintos. Utilizando a montagem para dar vários significados às imagens, Warburg não buscava oferecer uma história da arte, mas, sim, "uma memória imprensada da história", uma história da imaginação humana (DIDI-HUBERMAN, 2002).

As relações entre imagens e imaginação geográfica podem ser exploradas por muitos caminhos; um deles pode passar por uma aproximação maior com a História da Arte. Se os geógrafos e cartógrafos preocupados com o estudo do significado das imagens seguem tendo como uma referência importante os trabalhos dos historiadores da Arte aqui citados, então talvez seja fundamental atualizar os debates realizados em torno desta escola. Para além de seguir citando as palavras iconografia e iconologia apenas como sinônimo de imagem, ou simplesmente aplicar este método sem debater suas limitações, pode-se buscar caminhos mais cautelosos quando se objetiva relacionar imagens e contextos históricos específicos.

Embora já tenham sido extensivamente discutidos em outros campos disciplinares, os dois "riscos" do método iconológico apresentados no presente artigo ainda parecem ameaçar consideravelmente o trabalho dos 
geógrafos. A existência de argumentos circulares parece ser recorrente em muitos artigos que, ao invés de se apropriarem das imagens como fonte de informação, as utilizam para comprovar teses previamente formuladas a partir de textos escritos. Por outro lado, os observadores não têm encontrado um lugar de destaque nas pesquisas geográficas com imagens. Alguns autores já discutem há bastante tempo as relações entre audiência, cultura visual e imaginação geográfica (i.e. MATLESS, 1996), mas os trabalhos que buscam estudar de maneira sistemática como os observadores participam do processo de significação das imagens ainda têm um amplo campo de desenvolvimento.

O reconhecimento da tímida discussão sobre metodologias de estudo das imagens na geografia foi um dos grandes estímulos para a elaboração deste artigo. Nenhum geógrafo deve achar que seu campo de conhecimento é suficiente para um debate profundo sobre o estudo das imagens, pois será apenas através de uma abordagem interdisciplinar, que busque compreender dilemas levantados por historiadores da arte, semiólogos, cientistas sociais e artistas, que se pode alcançar uma compreensão mais satisfatória do papel das imagens na produção e na imaginação do espaço. Ao destacar a inovação e as limitações de uma das primeiras disciplinas acadêmicas preocupadas em relacionar imagem e significado, o presente artigo pretende contribuir para uma apropriação menos imediata e mais reflexiva dos termos iconografia e iconologia no estudo das imagens em Geografia.
Ao evitar argumentos circulares e totalidades históricas absolutas, podem-se construir relações menos imediatas entre as imagens e os seus contextos históricos de produção e circulação. Como nos mostrava Warburg com seu Atlas, são muitas as formas possíveis de se contar histórias através das imagens.

\section{REFERÊNCIAS BIBLIOGRÁFICAS}

ALLEN. J. L. Lands of Myth, Waters of Wonder: The Place of Imagination in The History of Geographical Exploration. In: LOWENTHAL, D. e BOWDEN, M. (eds): Geographies of the Mind: Essays in Historical Geosophy. New York and Oxford. Oxford University Press, 1971.

ARGAN, G. C. Ideology and Iconology. In: MITCHELL, W. J. $\mathrm{T}$. (org), The Language of Images. Chicago and London. University of Chicago Press, 1980.

CASSIDY, B. Iconography at the Crossroads. Papers from the Colloquium sponsored by the Index of Christian art Princeton University. Princeton University Press, 1993.

CORRÊA, R. L. Formas Simbólicas e Espaço - algumas considerações. Aurora Geography Journal. Ano 1 Dec. Universidade do Minho, 2007.

COSGROVE, D. Social Formation and Symbolic Landscape. London, Croom Helm, 1984.

COSGROVE, D. e DANIELS, S. (orgs). The Iconography of Landscape. Cambridge, Cambridge University Press, 1987.

COSGROVE, D. Worlds of Meaning: Cultural Geography and the Imagination. In: FOOTE, K. E., HUGILL, P. J. (et alli) (eds) Re-reading Cultural Geography. Austin. University of Texas Press, 1994.

Geography and Vision. An Inaugural Lecture by Danis Cosgrove. Presented at Royal Holloway, University of London on February 29, 1996.

. Mappings. London: Reaktion Books, 1998.

COSGROVE, D. e JACKSON, P. Novos Rumos da Geografia Cultural. In: Corrêa, R. L. e Rosendahl, Z. (orgs) Geografia Cultural: Um Século (2). Rio de Janeiro. EdUERJ. p. 15-32, 2000.

CRARY, J. Techiniques of the Observer: On Vision and Modernity in the Nineteenth Century. Cambridge, MA:MIT, 1990.

DIDI-HUBERMAN, G. L'Image Survivante - Histoire de L'Art et Temps des Fantômes selon Aby Warburg. Paris: Les Edicion de Minuit, 2002. 
GINZBURG, C. De A. Warburg a E. H. Gombrich: Notas sobre um problema de método. In: GINZBURG, C. Mitos, Emblemas e Sinais. Morfologia e História. São Paulo. Companhia das Letras, 1989.

GOMBRICH, E. Aims and Limits of Iconology. In: The Essential Gombrich. Hong Kong: Haidon, 1996.

Aby Warburg: His Aims and Methods: An Anniversary Lecture. Journal of the Warburg and Courtauld Institutes, Vol. 62, pp. 268-282, 1999

Meditações sobre um Cavalinho de Pau e Outros ensaios sobre a Teoria da Arte. Tradução de Geraldo Gerson de Souza. São Paulo. Edusp, 1999.

GOMES, P. C. Cenários para a Geografia: sobre a espacialidade das imagens e suas significações. In: Correa e Rosendhal, Espaço e Cultura: Pluralidade Temática. EdUERJ, 2008.

HARLEY, J. B. e BLAKEMORE, M. J. and. Concepts in the History of Cartography: A Review and Perspective, Cartographica, 17, 4 (Monograph 26), 1980

HARLEY, J. B. "Maps, Knowledge and Power". In: D. E. COSGROOVE e S. DANIELS (eds.). The Iconography of Landscape. Cambridge. University of Cambridge Press. p.277312,1988

HECKSCHER, W. S. Erwin Panofsky: A Curriculum Vitae. Record of the Art Museum, Princeton University, Vol. 28, No. 1, Erwin Panofsky: In Memoriam, pp. 4-21, 1969.

"The Genesis of Iconology". In: VERHEYEN, DURHAM, N. C. and BADEN-BADEN. Art and Literature, Study in Relationship, 1985.

KOSONEN, K. Maps, newspapers and nationalism: The Finnish historical experience. GeoJournal, 48, 91-100, 1999.

KWINTER, S. Panofsky, Perspective as Symbolic Form. Cambridge, MA. Zone Books, 1991

MANGHANI, S. et alli Images: a reader. London. Sage Publications, 2006

MATLESS, D. Visual culture and geographical citizenship: England in the 1940s. Journal of Historical Geography 22:424439,1996

MITCHELL, W. J. T. Iconology: Image, Text, Ideology, Chicago, University of Chicago Press, 1986.
Picture Theory Essays on Verbal and Visual Representation. Chicago and London. University of Chicago Press, 1994.

NOVAES, R. A. "A Iconografia das Drogas na Imprensa (1975 2002)". Rio de Janeiro, Dissertação de Mestrado, PPGG/UFRJ, 2005.

A cartografia sobre as drogas ilícitas na cartografia brasileira: omissão e destaques nos mapas jornalísticos. Aurora Geography Journal, ano 1, dec. 2007.

A cartografia jornalística: imagem e significado. Um estudo da representação das drogas ilícitas na imprensa brasileira. In: Corrêa, R. L. e Rosendahl, Z. (org.) Espaço e Cultura: pluralidade temática. Rio de Janeiro: EdUERJ, 2008

PANOFSKY, E. Note on the Importance of Iconographical Exactitude. The Art Bulletin, Vol. 21, No. 4 (Dec., 1939), p. 402, 1939.

Significado nas Artes Visuais. São Paulo. Ed. Perspectiva, (1 ${ }^{\circ}$ edição de 1955), 1979.

Perspective as Symbolic Form. New York. Zone Books. (1 ${ }^{\circ}$ edição de 1925), 1997

ROSE, G. Engendering the slum: Photography in East London in the 1930s. Gender, Place and Culture 4, 277-300, 1997

Visual Methodologies. An Introduction to the $\overline{\text { Interpretation }}$ of Visual Materials. London. Sage publications, 2001.

On the need to ask how, exactly, is geography "visual"? Antipode 35(2):212-221, 2003.

SALX, F. La vida de las imágenes. Estudios Iconográficos sobre el arte ocidental. Barcelona. Alianza Editorial. (original de 1933), 1957.

STRATEN, R. V. An Introduction to Iconography. Amsterdam. Gordon and Breach, 1994

WOOD, C. Introduction. In: Panofsky, Perspective as Symbolic Form. Cambridge, MA. Zone Books, 1991.

WOODFIELD, R. (ed.) Art history as Cultural history. Warburg's Projects. Amsterdam. Biel. Londin. University Press, 2001. 
ABSTRACT: THE "SCHOOL" OF ART HISTORIANS DEVELOPED AROUND THE IDEAS OF ABY WARBURG IN THE EARLY TWENTIETH CENTURY HAS HAD PECULIAR INFLUENCE ON THE RELATIONS BETWEEN ART THEORY AND CONTEMPORARY HUMAN GEOGRAPHY. BY DISCUSSING THE MEANINGS OF LANDSCAPES, MAPS, PHOTOGRAPHS AND PAINTINGS, MANY AUTHORS HAVE USED VISUAL METHODS FROM ART HISTORIANS SUCH AS ICONOGRAPHY AND ICONOLOGY. THIS PAPER AIMS TO EXPLORE TWO CRITICISMS TOWARDS THE ICONOLOGICAL METHOD - THE DANGER OF CIRCULAR ARGUMENTS AND THE NEGLIGENCE OF THE OBSERVER -, IN ORDER TO STIMULATE INTERDISCIPLINARY DEBATES ON THE USE OF IMAGES AS A SOURCE OF INFORMATION FOR GEOGRAPHICAL INVESTIGATION.

KEYWORDS: ICONOLOGY, GEOGRAPHY, HISTORY OF ART.

GEOGRAFIA Y HISTORIA DEL ARTE: NOTAS PARA UNA CRITICA A ICONOLOGIA

RESUMEN: LA "ESCUELA" DE LOS HISTORIADORES DEL ARTE FORMADA EN TORNO DE LAS IDEAS DE ABY WARBURG A PRINCIPIOS DEL SIGLO XX HA TENIDO UNA INFLUENCIA PARTICULAR EN EL CAMBIO ENTRE LAS TEORÍAS ARTÍSTICAS Y EL TRABAJO DE LOS GEÓGRAFOS CONTEMPORÁNEOS. INTERESADOS EN DISCUTIR LOS SIGNIFICADOS DE PAISAJES, MAPAS, FOTOGRAFÍAS Y PINTURAS, MUCHOS AUTORES SE HAN APROPIADO DE LA ICONOGRAFÍA Y LA ICONOLOGÍA COMO HERRAMIENTAS METODOLÓGICAS. EN VISTA DE DOS CRÍtICAS DIRIGIDAS HACIA EL MÉTODO ICONOLÓGICO - EL PELIGRO DE LOS ARGUMENTOS CIRCULARES Y EL ABANDONO DEL OBSERVADOR -, ESTE ARTíCULO SE PRETENDE ESTIMULAR EL DEBATE INTERDISCIPLINARIO SOBRE EL USO DE LAS IMÁGENES COMO FUENTE DE INFORMACIÓN EN LA INVESTIGACIÓN GEOGRÁFICA.

PALABRAS-CLAVE: ICONOLOGÍA, GEOGRAFíA, HISTORIA DEL ARTE. 
ESPAÇO E CULTURA, UERJ, RJ, N. 33, P.43-64, JAN./JUN. DE 2013

http://www.e-publicacoes.uerj.br/index.php/espacoecultura/ 